\title{
Design of Mechanical Smoke Exhaust System in Large Space of Convention Center
}

\author{
Jung-Yup Kim*, Chan-Sol Ahn \\ Multi Disaster Countermeasures Organization, Korea Institute of Civil Engineering and Building Technology, Goyang, \\ Korea \\ Email: ${ }^{*}$ jykim1@kict.re.kr
}

How to cite this paper: Kim, J.-Y. and Ahn, C.-S. (2017) Design of Mechanical Smoke Exhaust System in Large Space of Convention Center. Open Journal of Fluid Dynamics, 7, 386-396.

https://doi.org/10.4236/ojfd.2017.73026

Received: September 4, 2017

Accepted: September 25, 2017

Published: September 28, 2017

Copyright ( 92017 by authors and Scientific Research Publishing Inc. This work is licensed under the Creative Commons Attribution International License (CC BY 4.0).

http://creativecommons.org/licenses/by/4.0/

\section{c) (7) Open Access}

\begin{abstract}
The volumetric flow rate of smoke generated from the fire in large space often reaches to hundreds of thousands CMH because of extended floor height and as it's more difficult to isolate the smoke to the limited area, comparing to normal-scale building, design and operation of effective smoke control system for large space is more than important. In this study, with the analysis model for such a large space as exhibition hall or conference room in conventional center, design of mechanical smoke exhaust system was conducted based on currently-available design standard which was then followed by numerical analysis of the design using 3D numerical analysis method. For conference room at 2.0 MW heat release rate, 99,173 CMH flow rate is required, if smoke layer is maintained at $60 \%$ of the floor height and for exhibition hall at 8.8 MW with $80 \%$ of floor height, flow rate required is $219,802 \mathrm{CMH}$, which are incorporated into the design. In view of $3 \mathrm{D}$ numerical analysis, accuracy of the design according to algebraic expression is sufficient.
\end{abstract}

\section{Keywords}

Smoke Control, Mechanical Exhaust System, Large Space, Convention Center, Numerical Analysis

\section{Introduction}

Construction of the structure with large space began in earnest in 1980s in line with the construction of indoor stadium for the booming international indoor sports events in Korea, which has maintained a growing tendency along with increasing number of large and complex buildings. The volumetric flow rate of smoke generated from the fire in large space often reaches to hundreds of thousands CMH because of extended floor height and as it's more difficult to isolate 
the smoke to the limited area, comparing to normal-scale building, design and operation of effective smoke control system for large space is more than important.

Recognizing the hazards caused by fire smoke in large space in many countries, smoke control design guideline for large space has been developed and proposed worldwide since 1980s [1] [2] and the study to enhance the reliability of smoke control analysis technologies in large space through a full-scale test is still in process now [3] [4] and recently, the measures to improve the smoke control system focusing on air supply and smoke exhaust efficiency is under review [5] [6] as well.

In this study, design of smoke safety system by mechanical smoke exhaust in conventional center was presented with the application of currently-available design standard then followed by 3D numerical analysis method.

\section{Design Guideline for Mechanical Smoke Exhaust System in Large Space}

In this study, design which was intended to apply mechanical smoke exhaust system in large space to a full-scale space analysis model for large space was conducted based on design guideline [1] in which algebraic expression-centered design process was described in detail.

Major design factors for mechanical smoke exhaust system in large space include the followings. Heat Release Rate $(Q)$ refers to initial fire development character which was assumed as Equation (1) that t-squared fire is selected and then hear release rate in steady-state character is occurred.

$$
Q=\alpha t^{2}
$$

where, $\alpha$ is the fire growth coefficient and $t$ is the time elapsed since the fire occurred. Convective Portion of Heat Release Rate, $\left(Q_{c}\right)$ is considered $70 \%$ of total Heat Release Rate.

Conditions of axisymmetric plumes were applied and mass flow rate of plume, $\left(m_{p}\right)$ representing smoke generation is determined according to following Equation (2)

$$
m_{p}=\left(0.071 Q_{c}^{1 / 3} H_{s}^{5 / 3}\right)+0.0018 Q_{c}
$$

where, $H_{s}$ is the smoke layer height.

Mechanical air is supplied at the bottom of smoke layer and to ensure the plume is generated and rises stably, air flow velocity is limited to $1 \mathrm{~m} / \mathrm{s}$.

To maintain the smoke exhaust efficiency on ceiling, flow rate per exhaust outlet and the spacing between exhaust outlets need to be designed to avoid plugholing. Maximum flow rate of exhaust outlet $\left(V_{\max }\right)$ per outlet is determined according to Equation (3) below:

$$
V_{\max }=4.16 \gamma d^{5 / 2}\left(\frac{T_{s}-T_{o}}{T_{o}}\right)^{1 / 2}
$$


where, $\gamma$ is location factor, $d$ is depth of smoke layer below the outlet, $T_{s}$ is temperature of smoke layer and $T_{o}$ is ambient temperature.

And the minimum distance between exhaust outlets $\left(S_{\min }\right)$ is determined according to following Equation (4)

$$
S_{\min }=0.065 V_{e}^{1 / 2}
$$

where, $V_{e}$ is exhaust flow rate per outlet.

\section{Application of Mechanical Smoke Exhaust System Design in Large Space}

\subsection{A Full-Scale Large Space Building}

The building subject to mechanical smoke exhaust system for large space is, as seen in Table 1, "S Convention Center" which is multi-purpose facilities for cultural \& meeting events, sales and business purpose. In the building designed as the strategic hub for the purpose of urban exhibition and conventional industry accommodates large conference rooms and exhibition halls for international events.

\subsection{Design of Mechanical Smoke Exhaust System in Large Space}

Floor height of conference room in S convention center (Figure 1) was designed with $14 \mathrm{~m}$ and the space is divided into 3 compartments. And heat release rate per unit area in case of the fire was estimated at $2.0 \mathrm{MW}$, referring to the data from the hotel [7].

Plume flow rate or smoke generation on assumption that smoke layer is maintained at $8.4 \mathrm{~m}$ height or $60 \%$ of floor height was estimated at 99,173 CMH

Table 1. A full-scale large space building.

\begin{tabular}{cc}
\hline Category & Description \\
\hline Project & Construction of S Convention Center \\
Site area & $50,005 \mathrm{~m}^{2}$ \\
Total floor area & $95,459.10 \mathrm{~m}^{2}$ \\
Use & Culture \& meeting facilities, sales, business facilities, \\
& Category 2 neighborhood living facilities \\
\hline
\end{tabular}

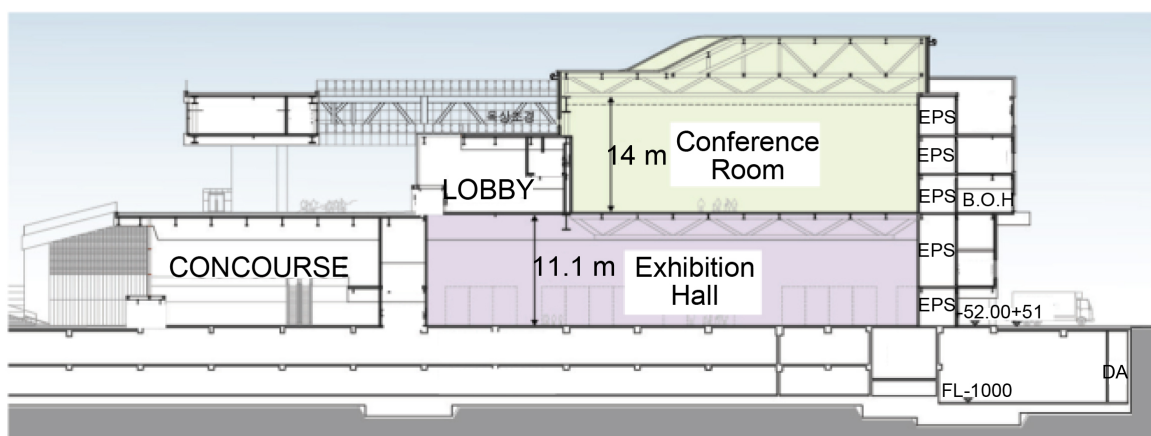

Figure 1. Section plan of S convention center. 
and smoke exhaust system was designed to accommodate $100 \%$ of such smoke generation and on the other hand, when smoke layer is maintained at $7.0 \mathrm{~m}$ or $50 \%$ of floor height, smoke exhaust requirement will be reduced to 77,590 $\mathrm{CMH}$.

But smoke exhaust system was not considered in existing conference room and thus, air duct needs to be provided to apply the smoke exhaust system. Ceiling duct for HVAC was installed in conference room and as exhaust capacity for HVAC was designed with 33,000 CMH per compartment, exhaust fan with additional capacity, as seen in Figure 2(a), is planned with the duct to be connected to each compartment. Air supply for smoke exhaust system is planned at the bottom of the wall in conference room and using existing air supply capacity for HVAC, 33,000 CMH will be secured and smoke exhaust fan to be installed will accommodate additional requirements, as seen in Figure 2(b).

Floor height of exhibition hall in S Convention center was designed with 11.1 $\mathrm{m}$ and heat release rate was estimated at $8.8 \mathrm{MW}$ referring to heat release rate per unit area of shops when the fire occurred at exhibition hall [7].

Given the relatively lower floor height of exhibition hall comparing to conference room, it's designed to maintain the smoke layer at $8.9 \mathrm{~m}$ or $80 \%$ of floor

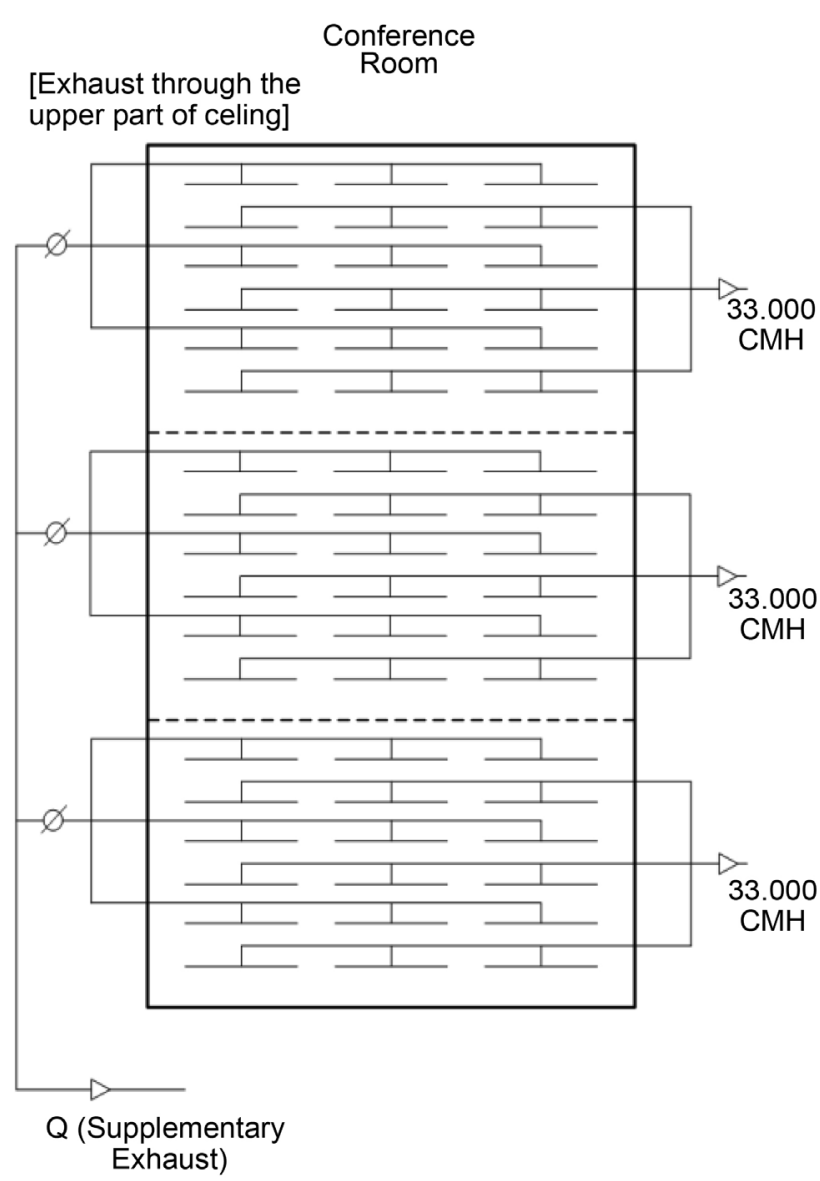

(a)

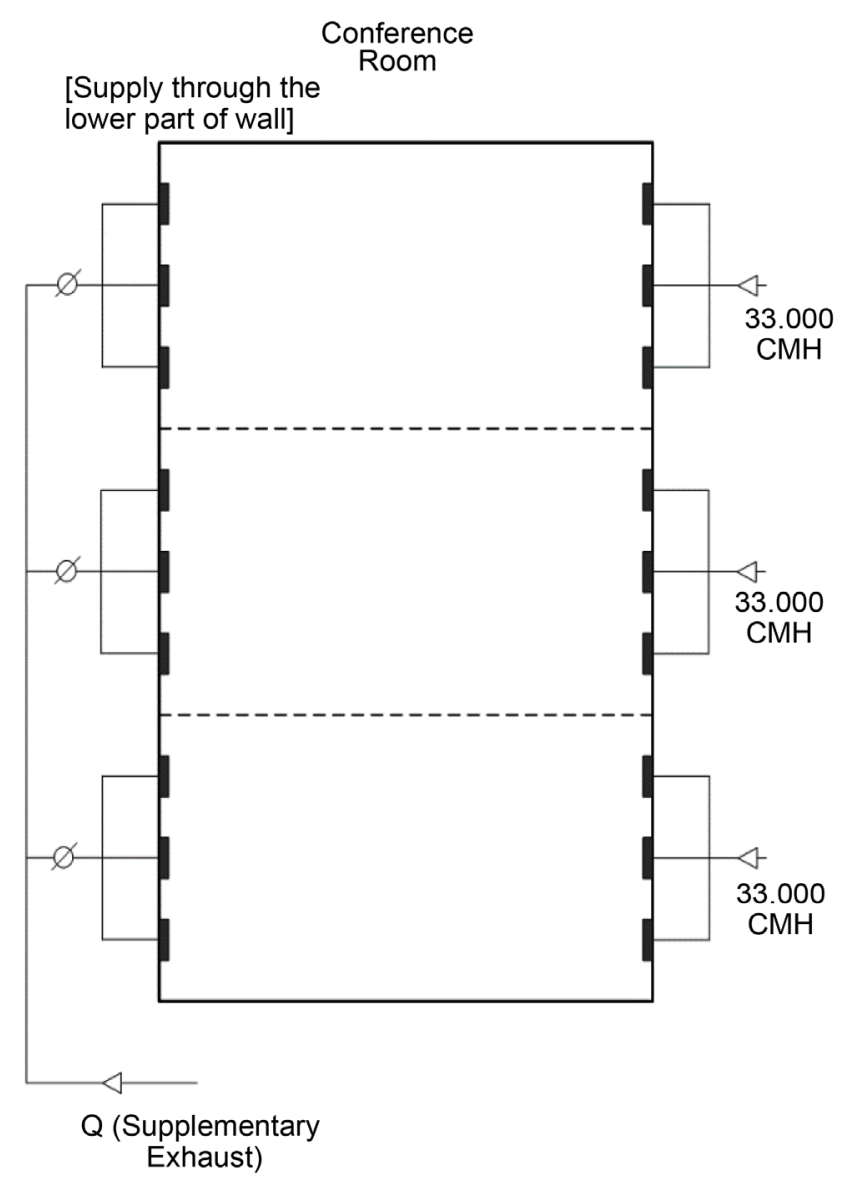

(b)

Figure 2. Air supply and exhaust plan for conference room: (a) Smoke exhaust plan on ceiling; (b) Air supply plan at the bottom of wall. 


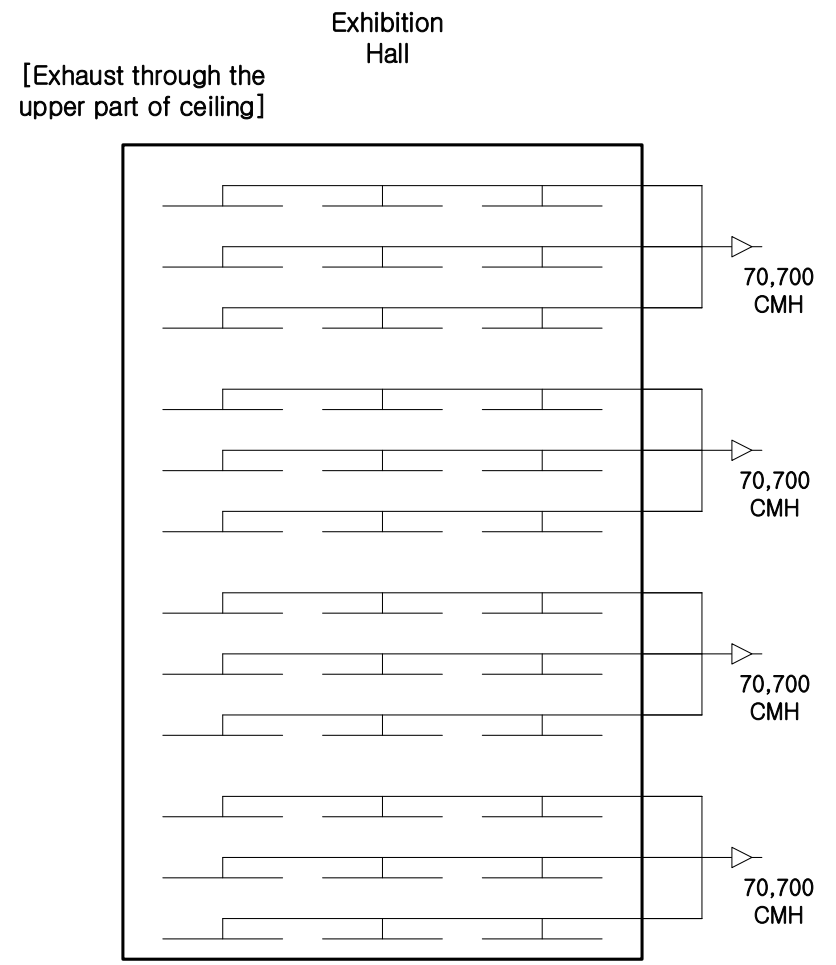

(a) height and in such a case, smoke exhaust requirement of 219,802 $\mathrm{CMH}$ was estimated as a result of calculating the plume flow rate or smoke generation. Like conference room, smoke exhaust system was not considered for exhibition hall too, and thus air supply and exhaust design was implemented to apply smoke exhaust system. When it comes to exhibition hall, whole space is open as a single space and ceiling duct was provided for HVAC and maximum 282,800 $\mathrm{CMH}$ smoke exhaust capacity could be secured, making use of air flow for HVAC. Air supply for smoke exhaust system is designed to perform at the bottom of wall in exhibition hall and the air supply capacity up to $282,800 \mathrm{CMH}$ could be secured when using the air flow for HVAC. Figure 3 shows air supply and exhaust plan for smoke exhaust system of exhibition hall.

\subsection{Numerical Analysis of Mechanical Smoke Exhaust System in Large Space}

For basic design of large capacity smoke exhaust system for S convention center which was conducted previously, design feasibility was reviewed using numerical analysis method. In numerical analysis, 3D program, FDS 6.3.2 which is commonly used for the fire was used [8].

Before implementing numerical analysis of conference room, numerical analysis model as seen in Figure 4 was developed. As seen in figure, conference room was divided into 3 compartments and it's assumed that the fire occurred in

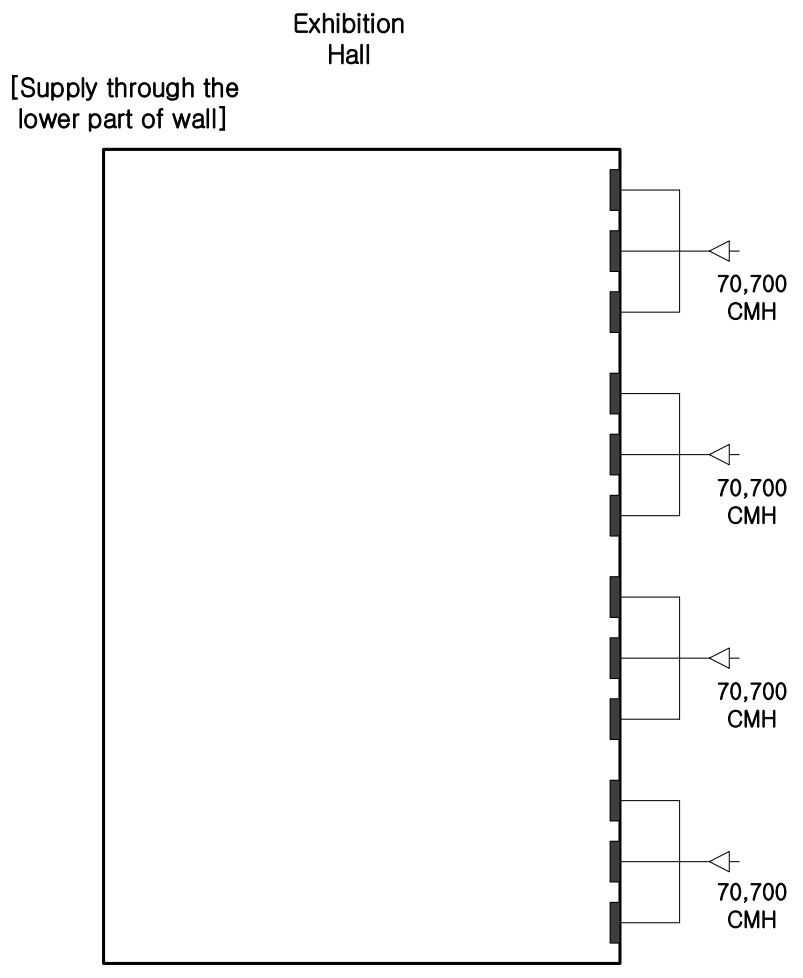

(b)

Figure 3. Air supply and exhaust plan for exhibition hall: (a) Smoke exhaust plan on ceiling; (b) Air supply plan at the bottom of wall. 


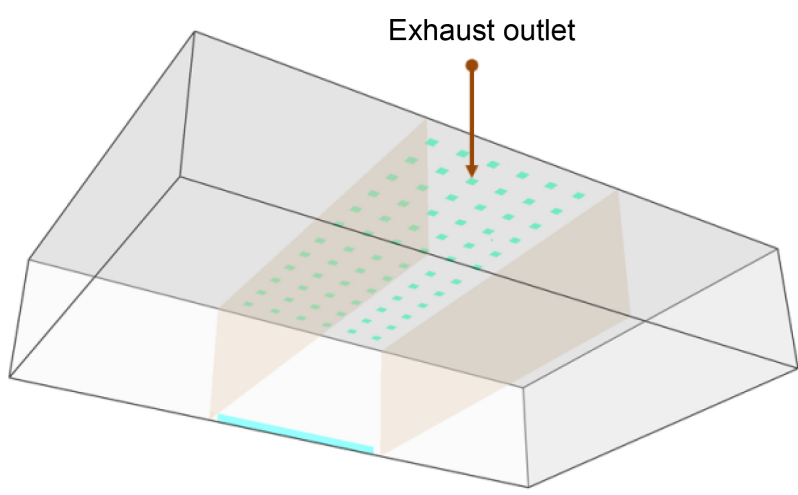

(a)

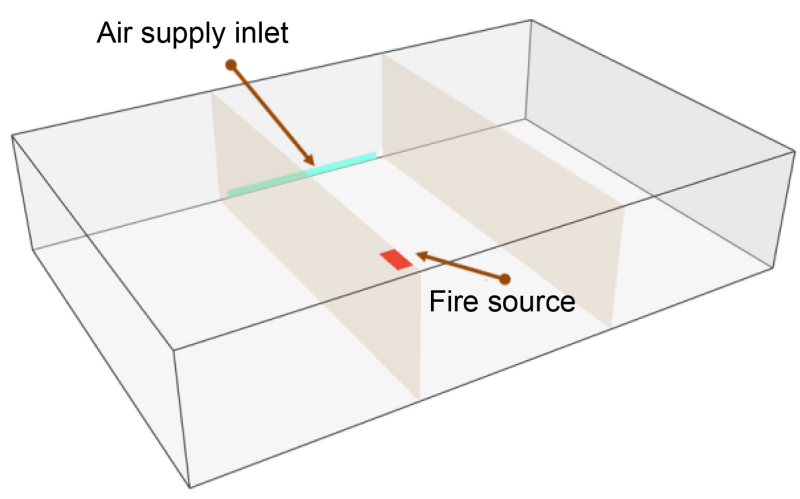

(b)

Figure 4. Numerical analysis model for conference room: (a) Exhaust outlet on top; (b) Air supply inlet at the bottom and fire source.

one of three compartments. Exhaust outlet was provided on top of the ceiling and air supply inlet was provided at the bottom of the wall. Heat release rate and flow rate at $60 \%$ of floor height was $2.0 \mathrm{MW}$ and $99,173 \mathrm{CMH}$, respectively and at $50 \%$ of floor height, it is $2.0 \mathrm{MW}$ and $77,590 \mathrm{CMH}$, respectively. As grid system of conference room for numerical analysis, the grid space is $0.5 \mathrm{~m}$ and total number of cells is about 340,000 .

Figures 5-7 show the numerical analysis results at $60 \%$ of floor height in conference room. Figure 5 shows the temperature distribution in each section 30 minutes after the fire occurred. As seen in figure, hot plume from the fire source reached the smoke layer on top and smoke layer was distributed at uniform thickness over entire area. Figure 6 shows the temperature measuring the points near the wall depending on height and the graph indicating the temperature varying over time. Temperature in upper part of room rose at early stage of fire due to hot smoke and the lower the height the slower the time taken for temperature rising and the less the temperature increase as well. Figure 7 shows the variation of smoke layer height over time at major points. Smoke layer was formed after the fire occurred, which began falling slowly in 3 minutes till 15 minutes and since then the height was maintained at $8.3 \mathrm{~m}$.

Figures 8-10 show the numerical analysis results in conference room at $50 \%$ of floor height. Figure 8 shows the temperature distribution in each section 30 minutes after the fire. Figure 9 illustrates the temperature values varying over time by height. It indicates the similar pattern as those at $60 \%$. Figure 10 shows the variation of smoke layer height over time at major points. Smoke layer was formed after the fire occurred which began falling slowly in 3 minutes till 20 minutes and since then the height was maintained at $6.7 \mathrm{~m}$.

A numerical analysis model was developed as seen in Figure 11 to perform numerical analysis of exhibition hall. As seen in figure, it's assumed that the fire occurred near the wall in exhibition hall and exhaust outlet was provided on ceiling over entire space of exhibition hall and air supply inlet was provide at the bottom of wall. For heat release rate and flow rate was assumed as $8.8 \mathrm{MW}$ and 


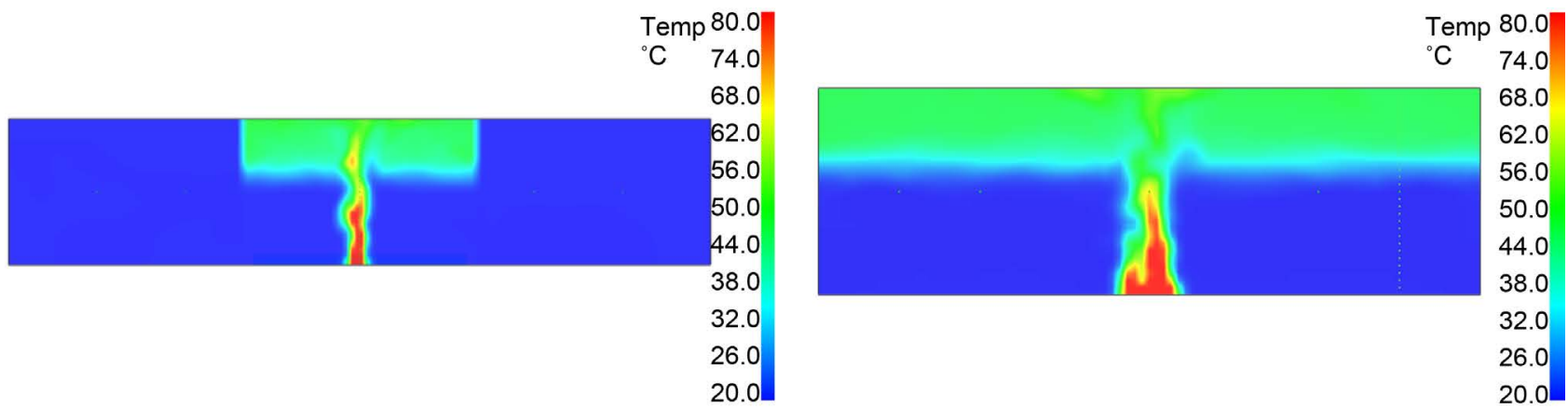

(a)

(b)

Figure 5. Temperature distributions in 30 minutes (conference room, 60\% of floor height): (a) Front; (b) Side.

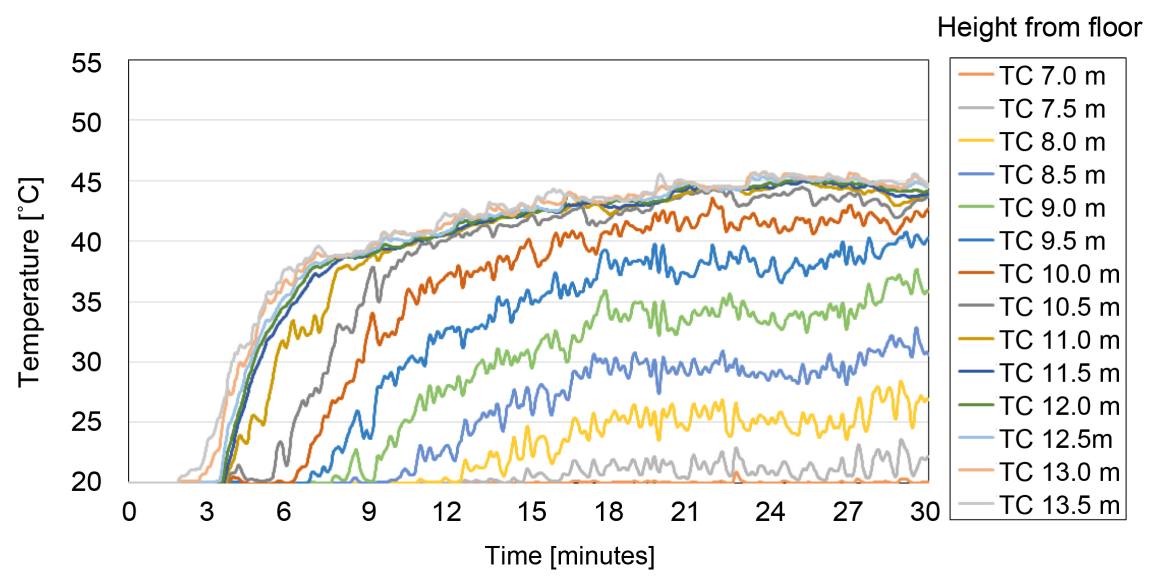

Figure 6. Temperature variations over time by height (conference room, $60 \%$ of floor height).

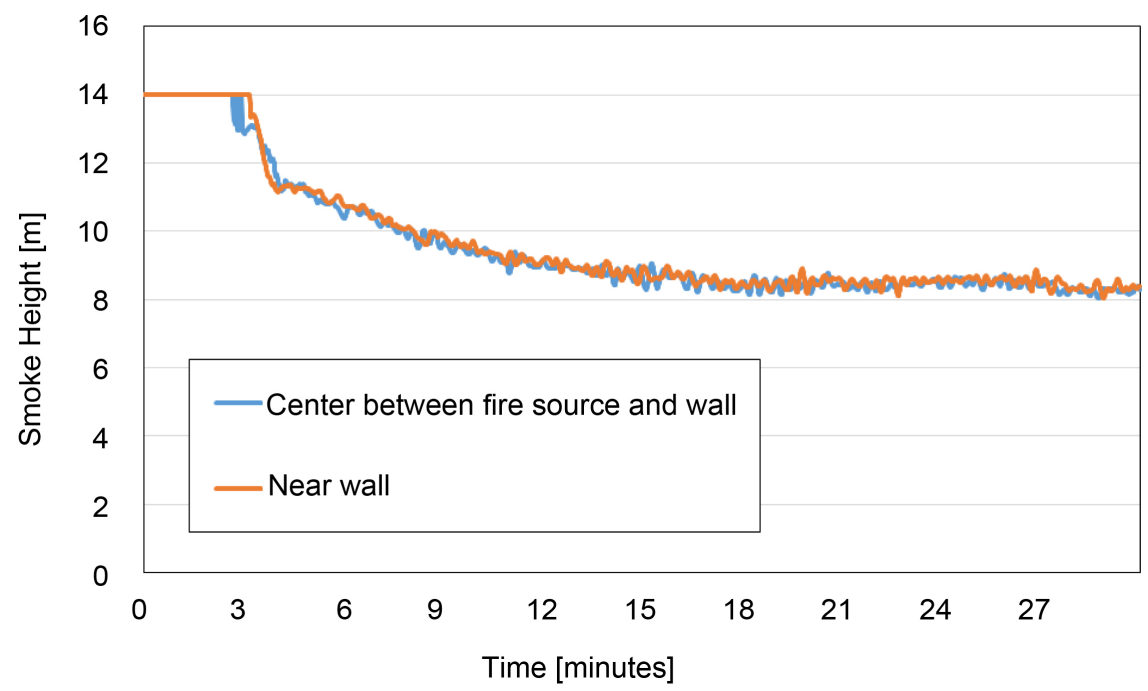

Figure 7. Variations of smoke layer height over time at major points (conference room, $60 \%$ of floor height).

$219,802 \mathrm{CMH}$, respectively, at $80 \%$ of floor height. As grid system of exhibition hall for numerical analysis, the grid space is $0.5 \mathrm{~m}$ and total number of cells is 


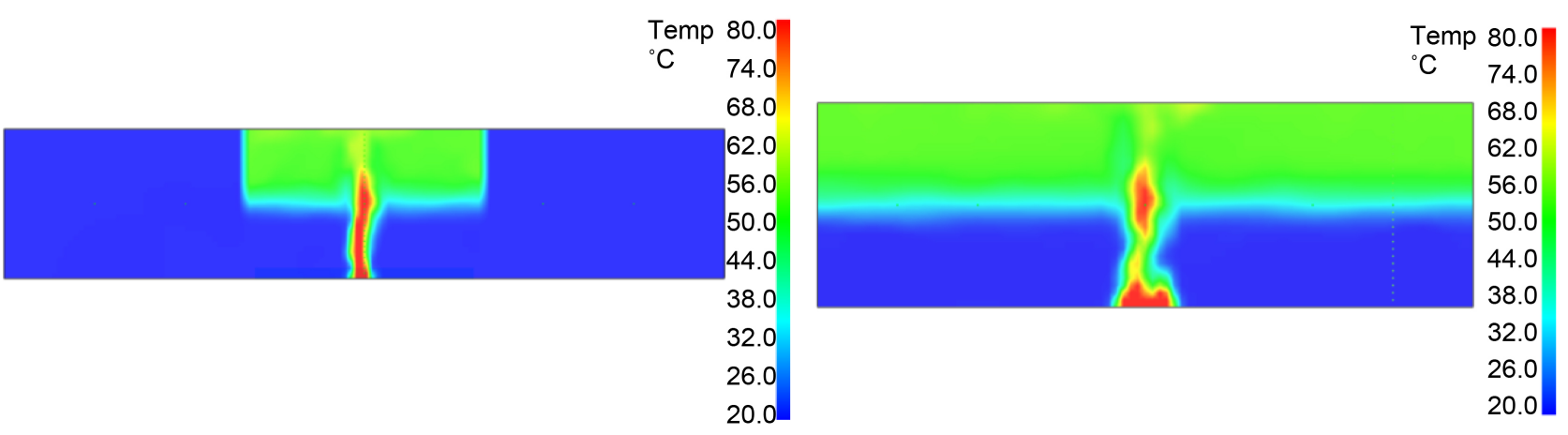

(a)

(b)

Figure 8. Temperature distributions in 30 minutes (conference room, 50\% of floor height): (a) Front; (b) Side.

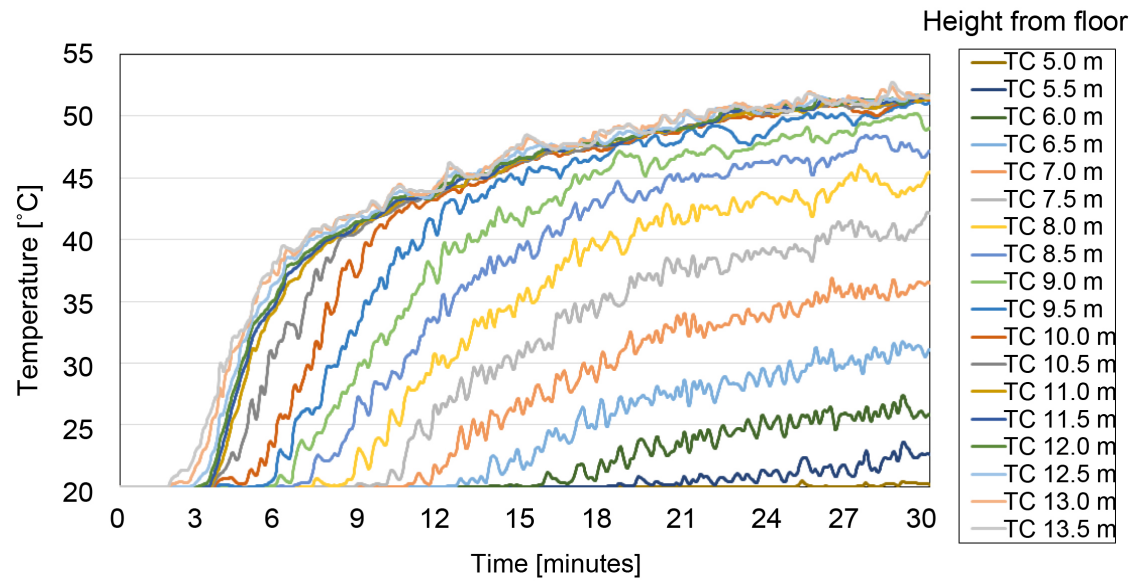

Figure 9. Temperature variations over time by height (conference room, 50\% of floor height).

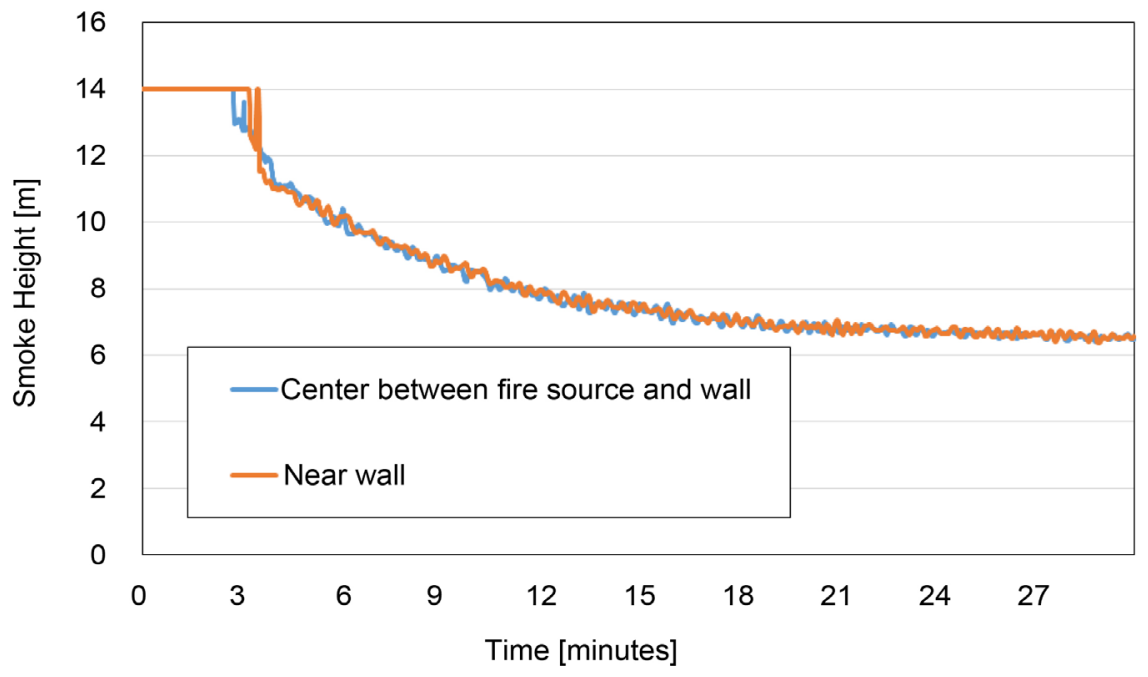

Figure 10. Variations of smoke layer height over time at major points (conference room, $50 \%$ of floor height).

about 700,000 .

Figures 12-14 show the numerical analysis results of exhibition hall. Figure 
12 shows temperature distribution in each section in 30 minutes after the fire occurred and Figure 13 illustrates the temperature values varying over time by height which were similar with the pattern of convention hall. Figure 14 shows smoke layer height varying over time at major points. As the exhibition hall has a large area, the time taken for smoke layer to reach the wall and fall was different by location and in 15 minutes, smoke layer was maintained at $8.2 \mathrm{~m}$ height.

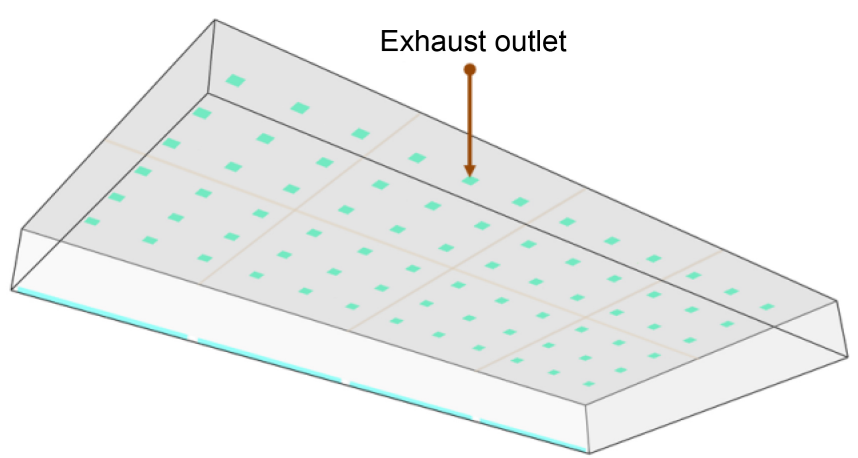

(a)

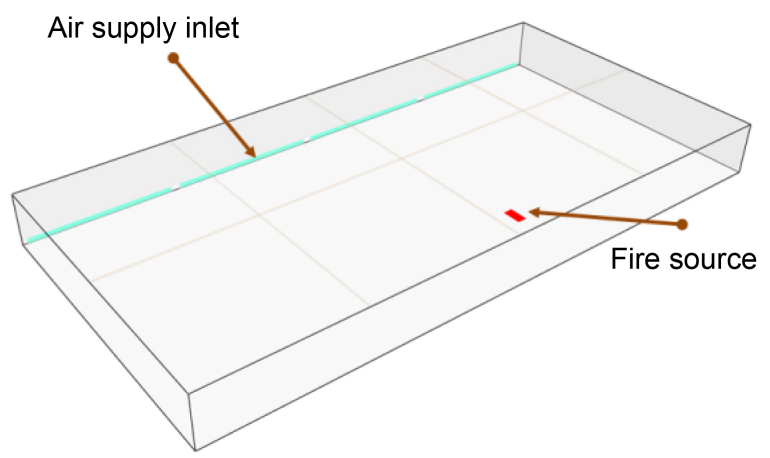

(b)

Figure 11. Numerical analysis model of exhibition hall: (a) Exhaust outlet on top; (b) Air supply inlet at the bottom and fire source.

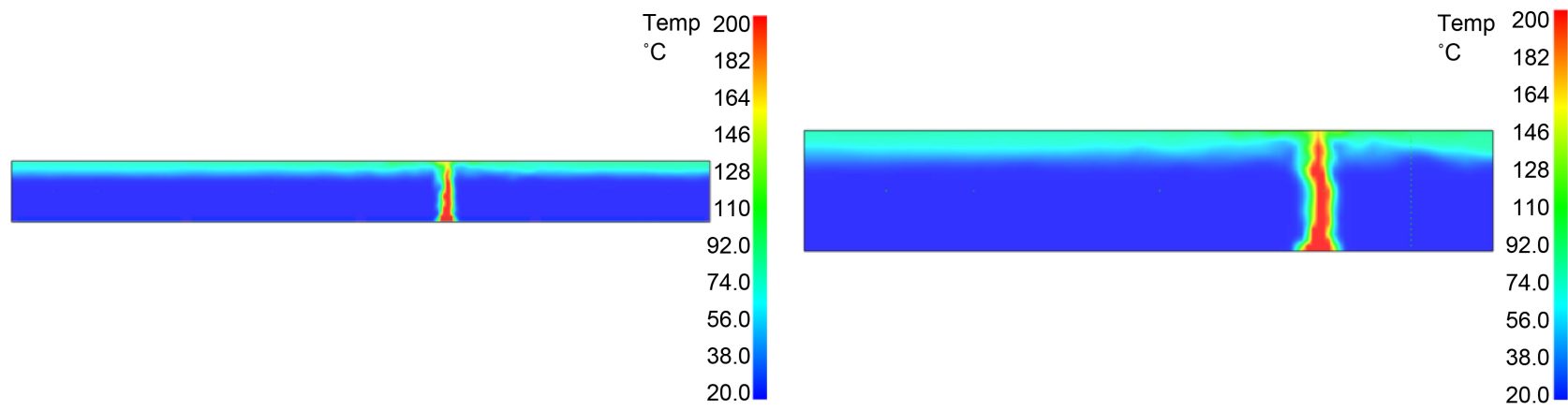

(a)

(b)

Figure 12. Temperature distributions in 30 minutes (exhibition hall, $80 \%$ of floor height): (a) Front; (b) Side.

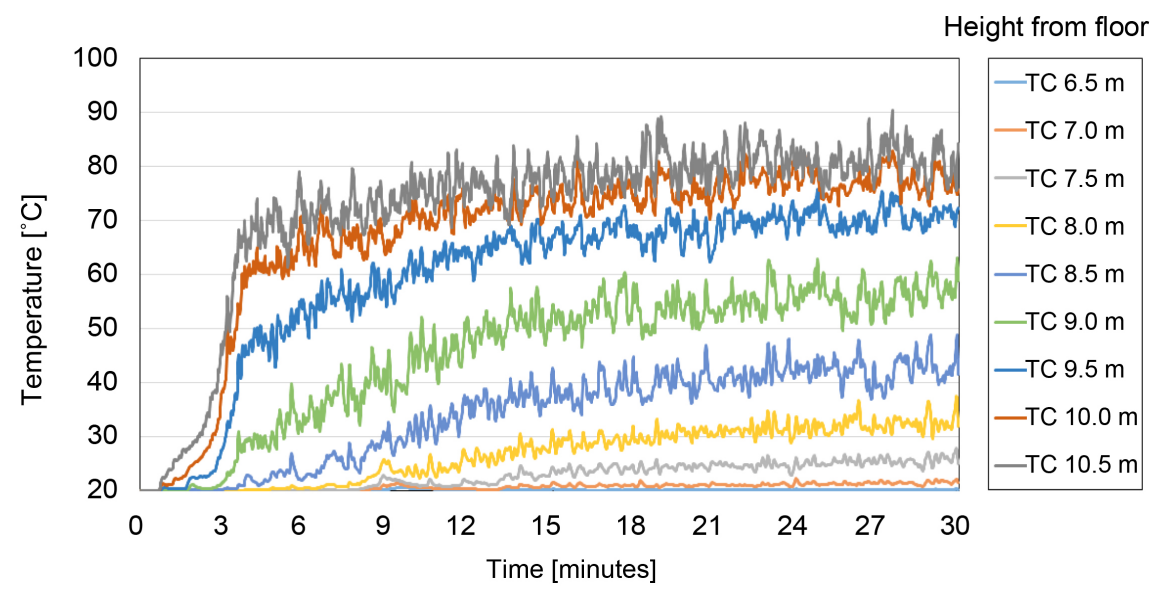

Figure 13. Temperature variations over time by height (exhibition hall, $80 \%$ of floor height). 


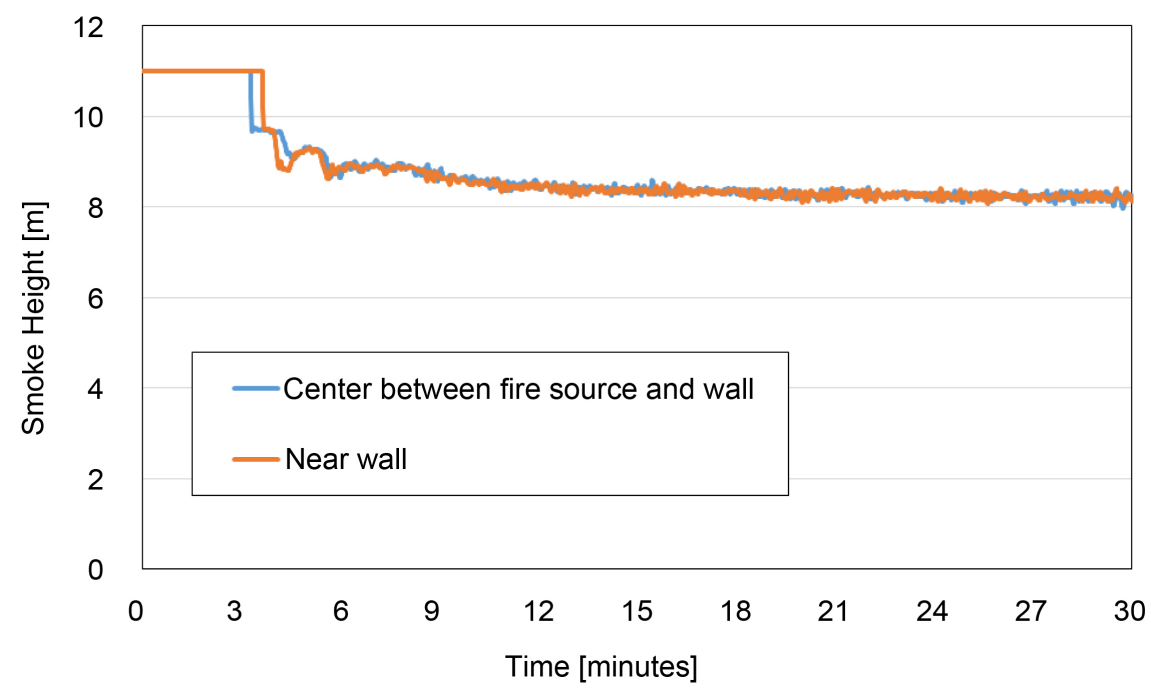

Figure 14. Variations of smoke layer height over time at major points (exhibition hall, 80\% of floor height).

\section{Conclusions}

In this study, with the analysis model for such a large space as exhibition hall or conference room at conventional center, design of mechanical smoke exhaust system was conducted based on currently-available design standard which was then followed by numerical analysis of the design using 3D numerical analysis method. Consequently, following conclusion was made:

1) For conference room at $2.0 \mathrm{MW}$ heat release rate, plume of smoke generation was estimated at $99,173 \mathrm{CMH}$, if smoke layer is maintained at $8.4 \mathrm{~m}$ or $60 \%$ of floor height. As a result of 3D numerical analysis, smoke layer height was maintained at $8.3 \mathrm{~m}$.

2) Smoke exhaust requirements could be reduced to $77,590 \mathrm{CMH}$, if the smoke layer is maintained at $7.0 \mathrm{~m}$ height or $50 \%$ of floor height of conference room. As a result of $3 \mathrm{D}$ numerical analysis after setting the heat release rate and airflow at 2.0 MW and 77,590 $\mathrm{CMH}$, respectively, in conference room, smoke layer height was maintained at $6.7 \mathrm{~m}$.

3) For exhibition hall at $8.8 \mathrm{MW}$ heat release rate, plume of smoke generation was estimated at $219,802 \mathrm{CMH}$, if smoke layer is maintained at $8.9 \mathrm{~m}$ or $80 \%$ of floor height. As a result of 3D numerical analysis, smoke layer height was maintained at $8.2 \mathrm{~m}$.

\section{Acknowledgements}

This study was conducted by the support of the project, "Development of performance-based fire safety design of the building and improvement of fire safety" (16AUDP-B100356-02) which is under the management of Korea Agency for Infrastructure Technology Advancement as part of the urban architecture research project for the Ministry of Land, Infrastructure and Transport, for which we extend our deep thanks. 


\section{References}

[1] National Fire Protection Association (2005) NFPA 92B: Standard for Smoke Management Systems in Malls, Atria, and Large Spaces.

[2] International Code Council (2012) International Building Code.

[3] Harrison, R. and Spearpoint, M. (2007) The Balcony Spill Plume: Entrainment of Air into a Flow from a Compartment Opening to a Higher Projecting Balcony. Fire Technology, 43, 301-317. https://doi.org/10.1007/s10694-007-0019-3

[4] Qin, T.X., Gue, Y.C., Chan, C.K. and Lin, W.Y. (2009) Numerical Simulation of the Spread of Smoke in an Atrium under Fire Scenario. Building and Environment, 44, 56-65. https://doi.org/10.1016/j.buildenv.2008.01.014

[5] Jie, J., Kaiyuan, L., Wei, Z. and Ran, H. (2010) Experimental Investigation on Influence of smoke Venting Velocity and Vent Height on Mechanical Smoke Exhaust Efficiency. Journal of Hazardous Materials, 177, 209-215. https://doi.org/10.1016/j.jhazmat.2009.12.019

[6] Gutierrez-Montes, C., Sanmiguel-Rojas, E. and Viedma, A. (2010) Influence of Different Make-Up Air Configurations on the Fire-Induced Conditions in an Atrium. Building and Environment, 45, 2458-2472. https://doi.org/10.1016/j.buildenv.2010.05.006

[7] British Standards Institution (2003) PD 7974-1: 2003 Application of Fire Safety Engineering Principles to the Design of Buildings-Part1: Initiation and Development of Fire within the Enclosure of Origin.

[8] National Institute of Standards and Technology (2016) Fire Dynamics Simulator (Version 6.3.2) User's Guide.

\section{Submit or recommend next manuscript to SCIRP and we will provide best service for you:}

Accepting pre-submission inquiries through Email, Facebook, LinkedIn, Twitter, etc. A wide selection of journals (inclusive of 9 subjects, more than 200 journals) Providing 24-hour high-quality service

User-friendly online submission system Fair and swift peer-review system Efficient typesetting and proofreading procedure Display of the result of downloads and visits, as well as the number of cited articles Maximum dissemination of your research work

Submit your manuscript at: http://papersubmission.scirp.org/

Or contact ojfd@scirp.org 